\title{
Syntheses and Crystal Structures of Tungsten Complexes Containing Various (Thiazoliumyl)diphenylphosphine Ligands
}

\author{
Kuang-H way Yih, Sung-Chih Yeh, Ying-Chih Lin,* Gene-Hsiang Lee, and \\ Yu Wang \\ Department of Chemistry, National Taiwan University, Taiped, Taiwan 106, Republic of China
}

Received May 20, 1997

\begin{abstract}
Alkylation reactions at the $\mathrm{S}$ atom of the anionic $\mathrm{PPh}_{2} \mathrm{C}(=\mathrm{NPh}) \mathrm{S}^{-}$ligand coordinated to a tungsten pentacarbonyl group afford the neutral complexes $\mathrm{W}(\mathrm{CO})_{5} \mathrm{PPh}_{2} \mathrm{C}(=\mathrm{NPh}) \mathrm{SR}(\mathbf{4}$, $\mathrm{R}=\mathrm{CH}_{2} \mathrm{C} \equiv \mathrm{CH} ; \mathbf{5}, \mathrm{R}=\mathrm{CH}_{2} \mathrm{C} \equiv \mathrm{N} ; \mathbf{6}, \mathrm{R}=\mathrm{CH}_{2} \mathrm{CONH}_{2} ; 7, \mathrm{R}=\mathrm{CH}_{2} \mathrm{CH}=\mathrm{CH}_{2} ; 8, \mathrm{R}=\mathrm{CH}_{2} \mathrm{CO}_{2^{-}}$ $\mathrm{Me})$. Protonation of $\mathbf{4}$ with $\mathrm{HBF}_{4}$ at room temperature causes cyclization to the cationic complex W(CO) $)_{5} \mathrm{PPh}_{2}\left[\mathrm{CSCH}_{2} \mathrm{C}\left(\mathrm{CH}_{2}\right) \mathrm{NPh}_{B} \mathrm{BF}_{4}(\mathbf{1 0})\right.$, which contains a (thiazoliumyl)diphenylphosphine ligand. Similarly, protonation reactions of $\mathbf{5}$ and $\mathbf{6}$ with $\mathrm{HBF}_{4}$ give the cationic complex $\left[\mathrm{W}(\mathrm{CO})_{5} \mathrm{PPh}_{2} \mathrm{CSCHC}\left(\mathrm{NH}_{2}\right) \mathrm{NPh}_{B} \mathrm{BF}_{4}(\mathbf{1 1}) \text { and the neutral complex W(CO) }\right)_{5} \mathrm{Ph}_{2} \mathrm{CSCHC}-$ $\left(\mathrm{OBF}_{3}\right) \mathrm{NPh}(\mathbf{1 2})$, respectively, both of which contain (thiazoliumyl)diphenyl phosphine ligands. The structures of $\mathbf{1 0}$ and $\mathbf{1 2}$ are determined by X-ray diffraction analyses.
\end{abstract}

\section{Introduction}

Thiazoles, mesoionic thiazoles, and thiazolium derivatives have attracted considerable attention because of their unusual charge distribution and possible aromatic properties of the five-membered rings. Some methods for the synthesis of thiazolium derivatives ${ }^{1}$ as well as bivalent metal thiazolium salts ${ }^{2}$ have been reported. Furthermore, much work has been carried out on the nucleophilic reactivity, ${ }^{3}$ cycloaddition reactions, ${ }^{4}$ and infrared, visible absorption, and resonance Raman ${ }^{5}$ studies of organic thiazolium compounds. However, only a few metal thiazolium derivatives have been reported. ${ }^{6}$ Our previous report dealt with alkylation reactions of the complex $\left[\mathrm{Et}_{4} \mathrm{~N}\right]\left[\mathrm{W}(\mathrm{CO})_{5} \mathrm{PPh}_{2}\left(\mathrm{CS}_{2}\right)\right]$ by unsaturated organic halides and their subsequent reactions. ${ }^{7}$ In this paper, we wish to report a new method for the synthesis of tungsten complexes containing (thiazoliumyl)diphenyl phosphine ligands.

(1) (a) Avalos, M.; Babiano, R.; Dianez, M.J .; Espinosa, J .; Estrada, M. D.; J iménez, J . L.; Lópe-Castro, A.; Méndez, M. M.; Palacios, J . C. Tetrahedron 1992, 48, 4193. (b) Potts, K. T.; Baum, J .; Datta, S. K. Houghton, E. J . Org. Chem. 1976, 41, 813.

(2) (a) Richardson, M. F.; Franklin, K.; Tompson, D. M. J . Am. Chem. Soc. 1975, 97, 3204. (b) Hadjiliadis, N.; Yannopoulos, A.; Bau, R. Inorg. Chim. Acta 1983, 69, 109. (c) Louloudi, M.; Hadjiliadis, N. J . Chem. Soc., Dalton Trans. 1991, 1635.

(3) (a) Pirotte, B.; Delarge, J . J . Chem. Res., Synop. 1990, 208. (b) Itoh, T.; Nagata, K.; Okada, M.; Ohsawa, A. Tetrahedron Lett. 1992, 33, 361.

(4) Cavalleri, P.; Clerici, F.; Erba, E.; Trimarco, P. Chem. Ber. 1992, $125,883$.

(5) Katayama, N.; Enomoto, S.; Sato, T.; Ozaki, Y. J . Phys. Chem. 1993, 97,6880

(6) (a) Cramer, R. E.; Maynard, R. B.; Evangelista, R. S. J . Am. Chem. Soc. 1984, 106, 111. (b) Aoki, K.; Yamazaki, H. J . Am. Chem. Soc. 1985, 107, 6242.

(7) (a) Yih, K. H.; Lin, Y. C.; Cheng, M. C.; Wang, Y. Organometallics 1994, 13, 1561. (b) Yih, K. H.; Lin, Y. C.; Cheng, M. C.; Wang, Y. J . Chem. Soc., Chem. Commun. 1995, 233.

\section{Results and Discussion}

Coordinated $\mathrm{PPh}_{2} \mathrm{C}(=\mathrm{NPh}) \mathrm{S}^{-}$Ligand and Its Alkylation Reactions. Facile deprotonation of $\mathrm{W}$ (CO) ${ }_{5} \mathrm{PPh}_{2} \mathrm{H}$ by $\mathrm{n}$-BuLi followed by exchange of the cation with $\mathrm{Et}_{4} \mathrm{NBr}$ gives $\mathrm{Et}_{4} \mathrm{~N}\left[\mathrm{~W}(\mathrm{CO})_{5} \mathrm{PPh}_{2}\right]$ (1). The IR spectrum of $\mathbf{1}$ has two relatively high frequency $\mathrm{CO}$ stretching bands at 2070 and $1910 \mathrm{~cm}^{-1}$, indicating that the ani onic charge is local ized at the phosphide ligand. Thus, treatment of $\mathbf{1}$ with $\mathrm{PhN}=\mathrm{C}=\mathrm{S}$ leads to the formation of a $\mathrm{P}-\mathrm{C}$ bond to give $\left[\mathrm{Et}_{4} \mathrm{~N}\right]\left[\mathrm{W}(\mathrm{CO})_{5} \mathrm{PPh}_{2} \mathrm{C}-\right.$ $(=\mathrm{NPh}) \mathrm{S}]$ (2a). ${ }^{8}$ Complex $\mathbf{2 a}$ can also be obtained directly from $\mathrm{W}(\mathrm{CO})_{5} \mathrm{PPh}_{2} \mathrm{H}$, without going through the isolation of $\mathbf{1}$, in ca. $85 \%$ yield. Complex $\mathbf{2 a}$ is an airstable yellow solid. The IR spectrum in the $v_{\text {CO }}$ region shows a pattern characteristic for an octahedral $\mathrm{M}(\mathrm{CO})_{5} \mathrm{~L}$ group, and the ${ }^{31} \mathrm{P}$ NMR spectrum shows a resonance at $\delta 34.3$ with J $w-p=238.9 \mathrm{~Hz}$. These data indicate a monodentate $\mathrm{P}$-coordination mode of the phosphine ligand in $\mathbf{2 a}$. This bonding mode contrasts with the chelation through $\mathrm{P}$ and $\mathrm{S}$ atoms by a similar ligand in complexes reported by Kunze and co-workers. ${ }^{9}$ Interestingly, there is no reaction between $\mathbf{1}$ and the aliphatic isothiocyanate $\mathrm{PhCH}_{2} \mathrm{~N}=\mathrm{C}=\mathrm{S}$. A reaction between $\mathrm{PhN}=\mathrm{C}=\mathrm{O}$ and $\mathbf{1}$ was found to occur, but no product could be isolated and identified.

Photolysis of $2 \mathbf{a}$ by UV radiation leads to loss of $\mathrm{CO}$ and formation of $\left[\mathrm{Et}_{4} \mathrm{~N}\right] \mathrm{W}(\mathrm{CO})_{4}\left[\eta^{2}-\mathrm{PPh}{ }_{2} \mathrm{C}(=\mathrm{NPh}) \mathrm{S}\right](3 \mathrm{a})$, in which the phosphine ligand binds to the metal in a

(8) (a) Yih, K. H.; Lin, Y. C.; Cheng, M. C.; Wang, Y.J . Chem. Soc. Chem. Commun. 1993, 1380. (b) Yih, K. H.; Lin, Y. C.; Cheng, M. C.; Wang, Y. J . Chem. Soc., Dalton Trans. 1995, 1305.

(9) (a) Kunze, U.; J awad, H.; Burghardt, R.; Tittmann, R.; Kruppa V. J. Organomet. Chem. 1986, 302, C30. (b) Antoniadis, A.; Kunze, U.; Moll, M. J . Organomet. Chem. 1982, 235, 177. (c) Ambrosius, $H$. P. M. M.; Bosman, W. P.; Cras, J . A. J . Organomet. Chem. 1981, 215, 201. 
Scheme 1

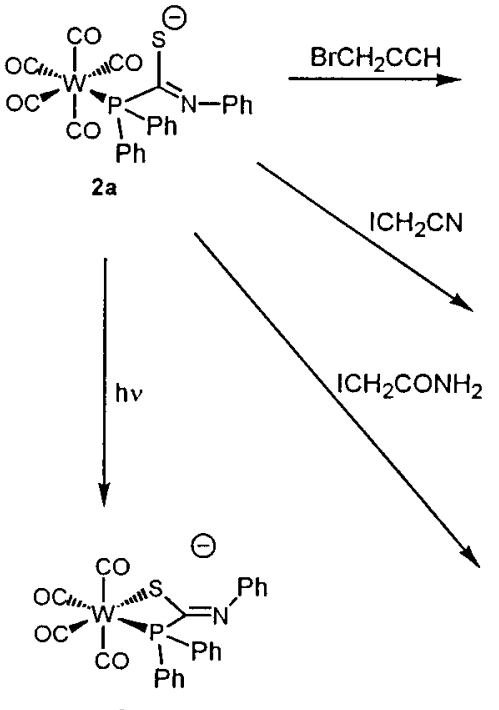

3a<smiles></smiles>

4<smiles>N#CCSC(=Nc1ccccc1)P(=O)(c1ccccc1)P([O-])(Cl)(Cl)Cl</smiles><smiles></smiles>

6

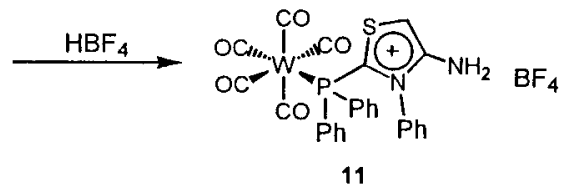

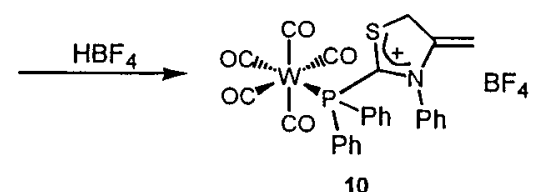

10

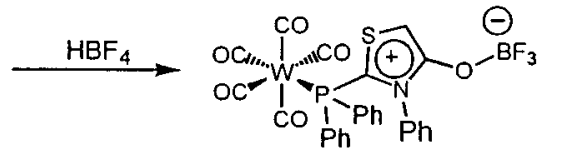

12 bidentate fashion through the $\mathrm{P}$ and $\mathrm{S}$ atoms. The IR spectrum of $3 a$ in the $v_{\mathrm{CO}}$ region displays four bands characteristic of a cis-M(CO) ${ }_{4} \mathrm{~L}_{2}$ group. The ${ }^{31 \mathrm{P}} \mathrm{NMR}$ resonance of 3a appears at $\delta 14.89$ with ${ }^{1} \mathrm{~J} w-\mathrm{p}=189.6$ $\mathrm{Hz}$, shifted from $\delta 34.3$ for $\mathbf{2 a}$. The different chemical shifts reflect the dissimilar bonding modes of the phosphine ligand. The bonding of the chelating phosphine ligand in $\mathbf{3 a}$ is analogous to that reported by Kunze and co-workers ${ }^{9}$ and is responsible for the inactive nature of $\mathbf{3 a}$. In comparison, the monodentate $\mathrm{P}$-coordinated bonding mode of the $\mathrm{PPh}_{2} \mathrm{C}(=\mathrm{NPh}) \mathrm{S}^{-}$ ligand in $\mathbf{2 a}$ results in this complex being much more reactive.

Surprisingly, the reaction of $\mathbf{1}$ with $\mathrm{EtOC}(\mathrm{O}) \mathrm{N}=\mathrm{C}=\mathrm{S}$ yields directly the decarbonylation product $\left[\mathrm{Et}_{4} \mathrm{~N}\right] \mathrm{W}$ $(\mathrm{CO})_{4}\left[\eta^{2}-\mathrm{PPh}_{2} \mathrm{C}\left(=\mathrm{NCO}_{2} \mathrm{Et}\right) \mathrm{S}\right](3 \mathbf{b})$, possibly due to higher photosensitivity or thermal reactivity of its precursor 2b. The $31 \mathrm{P}$ NMR spectrum of the phosphine ligand in $\mathbf{3 b}$ has a resonance at $\delta 16.36{ }^{(1 \mathrm{~J}} \mathrm{w}-\mathrm{p}=193.8 \mathrm{~Hz}$ ).

The alkylation reaction of $\mathbf{2 a}$ with alkyl halides leads to formation of a $\mathrm{S}-\mathrm{C}$ bond. Thus, the reaction of $\mathbf{2 a}$ with $\mathrm{BrCH}_{2} \mathrm{C} \equiv \mathrm{CH}$ affords the neutral complex W(CO) $5_{5}$ $\mathrm{PPh}_{2} \mathrm{C}(=\mathrm{NPh}) \mathrm{SCH}_{2} \mathrm{C} \equiv \mathrm{CH}(4)$ in $84 \%$ yield. In the $\mathrm{FAB}$ mass spectrum of $\mathbf{4}$, the parent peaks as well as the peaks due to fragmentation are in agreement with the molecular formula. The IR spectrum of $\mathbf{4}$ shows two terminal carbonyl stretchings at 2073 and $1934 \mathrm{~cm}^{-1}$. The higher frequencies compared to those of $\mathbf{2 a}$ indicate that $\mathbf{4}$ is a neutral complex. The ${ }^{31 P}$ NMR spectrum of 4 has a resonance at $\delta 38.03$ with a pair of tungsten satellites $\left({ }^{1} \mathrm{~J} w-p=246.8 \mathrm{~Hz}\right)$, similar to that of $\mathbf{2 a}$, indicating monodentate phosphorus coordination. In the ${ }^{1} \mathrm{H}$ NMR spectrum of $\mathbf{4}$, a doublet resonance at $\delta$ 2.88 and a triplet resonance at $\delta 2.04$ with ${ }^{4} \mathrm{~J}_{\mathrm{H}-\mathrm{H}}=1.80$ $\mathrm{Hz}$ are assigned to the S-methylene and terminal methyne protons of the propargyl group, respectively. In the ${ }^{13} \mathrm{C}$ NMR spectrum the corresponding ${ }^{13} \mathrm{C}$ resonances appear at $\delta 21.6$ and 72.8, respectively.

The synthetic methodology described above is applicable to primary organic halides with various substituents. Thus, the reaction of $\mathbf{2 a}$ with $\mathrm{ICH}_{2} \mathrm{C} \equiv \mathrm{N}$ in $\mathrm{CH}_{2} \mathrm{Cl}_{2}$ affords $\mathrm{W}(\mathrm{CO})_{5} \mathrm{PPh}_{2} \mathrm{C}(=\mathrm{NPh}) \mathrm{SCH}_{2} \mathrm{C} \equiv \mathrm{N}$ (5) in
$88 \%$ yield. The ${ }^{31 P}$ NMR spectrum of $\mathbf{5}$ ( $\delta 38.72$ with IJ $w-p=247.4 \mathrm{~Hz}$ ) is similar to that of 4 . The reaction of $\mathbf{2 a}$ with $\mathrm{ICH}_{2} \mathrm{CONH}_{2}$ affords the analogous complex $\mathrm{W}(\mathrm{CO}){ }_{5} \mathrm{PPh}_{2} \mathrm{C}(=\mathrm{NPh}) \mathrm{SCH}_{2} \mathrm{CONH}_{2}$ (6) in high yield. The same procedure was used to prepare $\mathrm{W}(\mathrm{CO})_{5} \mathrm{PPh}_{2-}$ $\mathrm{C}(=\mathrm{NPh}) \mathrm{SCH}_{2} \mathrm{CH}=\mathrm{CH}_{2}(7)$ and $\mathrm{W}(\mathrm{CO})_{5} \mathrm{PPh}_{2} \mathrm{C}(=\mathrm{NPh})$ $\mathrm{SCH}_{2} \mathrm{CO}_{2} \mathrm{Me}(\mathbf{8})$, both in high yield. In the reactions of $2 \mathbf{2 a}$ with various acyl halides, both S-acylation and $\mathrm{N}$-acylation are observed. ${ }^{10}$

Proton-Induced Cyclization. We previously reported spontaneous intermolecular cycloaddition ${ }^{7}$ of $\mathrm{W}(\mathrm{CO})_{5} \mathrm{PPh}_{2} \mathrm{C}(=\mathrm{S}) \mathrm{SCH}_{2} \mathrm{C} \equiv \mathrm{CH}$ (9) leading to dimerization. In the presence of $\mathrm{Et}_{3} \mathrm{~N}$ or $\mathrm{PhCH}_{2} \mathrm{NH}_{2}$, a different type of dimerization of $\mathbf{9}$ yields a dinuclear complex of 6a-thiathiophthene. ${ }^{8}$ However, unlike 9 , complex 4, by itself or in the presence of an amine, is stable. Protonation of $\mathbf{4}$ by $\mathrm{HBF}_{4}$ in $\mathrm{n}$-hexane at room temperature results in formation of $\mathrm{W}(\mathrm{CO})_{5} \mathrm{PPh}_{2}\left[\mathrm{CSCH}_{2} \mathrm{C}\left(\mathrm{CH}_{2}\right) \mathrm{NPh}\right]-$ $\mathrm{BF}_{4}$ (10) (see Scheme 1). The ${ }^{1} \mathrm{H}$ NMR spectrum of $\mathbf{1 0}$ has a resonance at $\delta 5.11$ assignable to the S-bonded methylene and a pair of resonances at $\delta 4.68$ and 5.65 assignable to the terminal methylene protons. The ${ }^{13} \mathrm{C}$ NMR signal of the S-bonded methylene is at $\delta 74.06$, while that of the terminal methylene carbon is masked by the aromatic carbon atoms.

Similarly, protonation of $\mathbf{5}$ by $\mathrm{HBF}_{4}$ results in the formation of the cationic cyclic complex [W(CO) ${ }_{5} \mathrm{PPh}_{2^{-}}$

$\mathrm{CSCHC}\left(\mathrm{NH}_{2}\right) \mathrm{NPh}_{\mathrm{BPF}}{ }_{4}$ (11), which contains a (thiazoliumyl)diphenyl phosphine ligand. In this reaction the proton-induced cyclization is also accompanied by a 1,3hydrogen shift. In the ${ }^{1} \mathrm{H}$ NMR spectrum of $\mathbf{1 1}$ the methyne proton appears at $\delta 6.22$. Protonation of 6 induces a similar cyclization with loss of a $\mathrm{NH}_{2}$ group

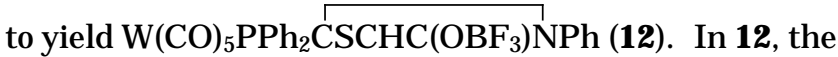
$\mathrm{BF}_{3}$ group acts as a Lewis acid and bonds to the oxygen atom of the enol group. Under similar reaction conditions complexes $\mathbf{7}$ and $\mathbf{8}$ are inert and no cyclization was observed.

(10) Yeh, S. C.; Yih, K. H.; Lin, Y. C.; Cheng, M. X.; Wang, Y. Manuscript in preparation. 


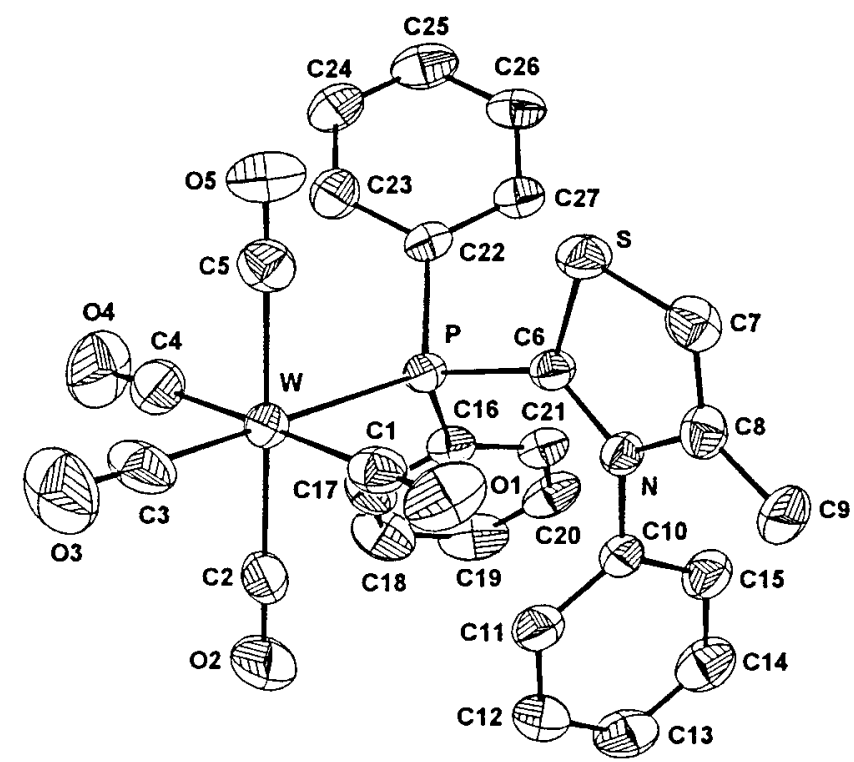

Figure 1. ORTEP drawing for the cation of $\mathrm{W}(\mathrm{CO})_{5^{-}}$ $\left[\mathrm{PPh}_{2} \mathrm{CSCH}_{2} \mathrm{C}\left(\mathrm{CH}_{2}\right) \mathrm{NPh}\right]\left[\mathrm{BF}_{4}\right]$ (10).

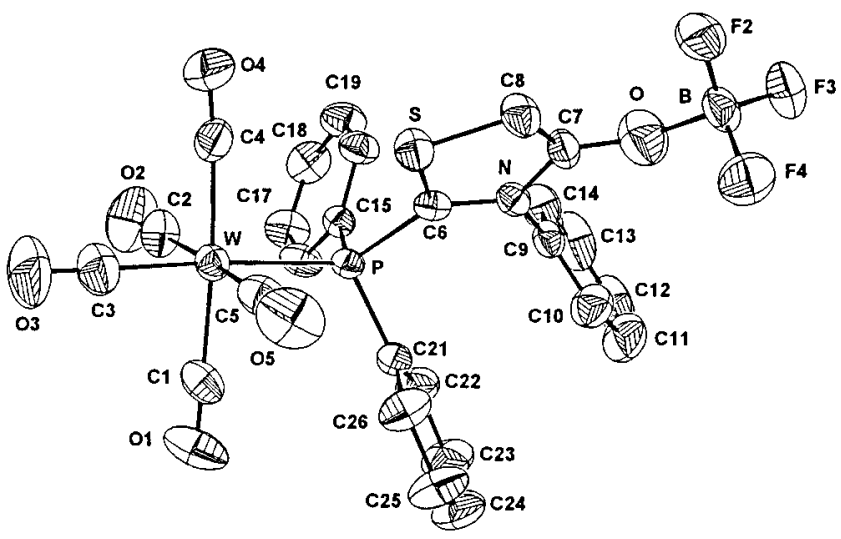

Figure 2. ORTEP drawing for $\mathrm{W}(\mathrm{CO})_{5}\left[\mathrm { PPh } _ { 2 } \longdiv { \mathrm { CSCHC } }\right.$ $\left.\left(\mathrm{OBF}_{3}\right) \mathrm{NPh}\right]$ (12).

Since the spectroscopic data of the thiazoliumylphosphine complexes are not sufficient for establishment of their structure, single crystals of $\mathbf{1 0}$ and $\mathbf{1 2}$ were grown and the structures determined by X-ray diffraction analysis. ORTEP drawings are shown in Figures 1 and 2 for 10 and 12, respectively. The coordination geometry around the tungsten metal center in $\mathbf{1 0}$ is pseudooctahedral. The phosphine ligand with a thioazolium group is coordinated to the tungsten metal center through the phosphorus atom. In the five-membered ring of 10, delocalization occurs only between the $\mathrm{S}-\mathrm{C}-\mathrm{N}$ atoms, as indicated by the bond distances C(6)-S (1.700(9) $\AA$ ) and C(6)-N (1.312(11) $\AA$ ), which show partial double-bond character, and the $\mathrm{C}(7)-\mathrm{C}(8)$ bond distance $(1.50(1) \AA)$, which is close to a normal $\mathrm{C}-\mathrm{C}$ single bond. It is thus not unexpected that the five atoms of the thiazolium ring are not planar. Deviations from the average plane are in the range of $0.12(1)$ to $-0.11(1) \AA$. The dihedral angle between the planes $\mathrm{S}-\mathrm{C}(6)-\mathrm{N}$ and $\mathrm{S}-\mathrm{C}(7)-\mathrm{C}(8)$ is $12.6(9)^{\circ}$. The bond length $C(8)-C(9)(1.307(15) \AA)$ is normal for a $C-C$ double bond.

In 12 the five-membered thiazolium ring is planar. The deviations from the average plane for all atoms are less than $0.006(5) \AA$. The $C(7)-C(8)(1.353(5) \AA)$ distance is in the range of a regular aromatic $\mathrm{C}-\mathrm{C}$ bond, confirming the presence of an enol unit (which is stabilized by $\mathrm{a} \mathrm{BF}_{3}$ group attached to the oxygen atom). The $\mathrm{BF}_{3}$ unit attached to an enol group has been observed in several diiron complexes. ${ }^{11}$ The bond distances $\mathrm{C}(6)-\mathrm{S}(1.669(3) \AA)$ and $\mathrm{C}(6)-\mathrm{N}(1.353(4) \AA)$ in 12 are comparable to the corresponding bond distances of 10, but the other $\mathrm{C}(8)-\mathrm{S}(1.691(4) \AA)$ ) distance is much shorter than the corresponding $\mathrm{C}(7)-\mathrm{S}$ (1.808(11) $\AA$ ) in 10. The thioazolium ring in $\mathbf{1 2}$ differs from the thiazole in $\mathbf{1 0}$ by protonation at $\mathrm{C}(\mathbf{7})$ in the latter.

A few thiazolium complexes are known, ${ }^{12}$ but their preparations do not involve protonation of a precursor. Formation of the intramolecular cyclization product $\mathbf{1 0}$ is believed to proceed via protonation at the terminal carbon of $\mathbf{4}$ to afford a cationic complex, followed by nucleophilic attack of the nitrogen atom of the PhNCS group at the center carbon of the propargyl unit to form the cationic thiazolium ring. In the reaction of $\mathbf{5}$ with acid, protonation very likely takes place at the nitrogen atom of the nitrile group, and the cyclization is followed by a 1,3-hydrogen shift, giving complex 11 . In the process of forming $\mathbf{1 2}$, the cyclization is accompanied by loss of the amine group and is further assisted by addition of $\mathrm{a} \mathrm{BF}_{3}$ group to the oxygen atom.

Treatment of $\mathbf{1 1}$ with $\mathrm{n}-\mathrm{Bu}_{4} \mathrm{NF}$ at room temperature affords $\mathrm{W}(\mathrm{CO})_{5} \mathrm{PPh}_{2} \mathrm{~F}$. The ${ }^{31 \mathrm{P}} \mathrm{NMR}$ spectrum of this product shows a doublet resonance at $\delta 171.37$ with $\mathrm{J}_{W-P}=148.4$ and $\mathrm{J}_{\mathrm{F}-\mathrm{P}}=862.2 \mathrm{~Hz}$, indicating $\mathrm{P}$ coordination of the $\mathrm{PPh}_{2} \mathrm{~F}$ ligand. Interestingly, treatment of analogous species $\mathbf{1 0}$ and $\mathbf{1 2}$ with $\mathrm{n}-\mathrm{Bu}{ }_{4} \mathrm{NF}$ gave no reaction under the same reaction conditions.

In conclusion, the facile synthesis of the $\mathrm{PPh}_{2} \mathrm{C}$ (=NPh)SR ligand coordinated to a tungsten pentacarbonyl group is reported. For $\mathrm{R}=$ propargyl, $\mathrm{CH}_{2} \mathrm{CN}$, and $\mathrm{CH}_{2} \mathrm{CONH}_{2}$, the organic part attached to the diphenylphosphine unit is converted to the thiazolium group by strong acid.

\section{Experimental Section}

General Procedures. All manipulations were performed under nitrogen using vacuum-line, drybox, and standard Schlenk techniques. $\mathrm{CH}_{3} \mathrm{CN}$ and $\mathrm{CH}_{2} \mathrm{Cl}_{2}$ were distilled from $\mathrm{CaH}_{2}$ and diethyl ether and THF from Na/ketyl. All other solvents and reagents were of reagent grade and were used without further purification. NMR spectra were recorded on the Bruker AC-200 and AM-300WB FT-NMR spectrometers at room temperature (unless stated otherwise) and are re ported in units of $\delta$ with residual protons in the solvent as an internal standard $\left(\mathrm{CDCl}_{3}, \delta 7.24 ; \mathrm{CD}_{3} \mathrm{CN}, \delta 1.93 ; \mathrm{C}_{2} \mathrm{D}_{6} \mathrm{CO}, \delta\right.$ 2.04). FAB mass spectra were recorded on a J EOL SX-102A spectrometer. Elemental analyses and X-ray diffraction studies were carried out at the Regional Center of Analytical Instrumentation located at the National Taiwan University. $\mathrm{W}(\mathrm{CO})_{6}$ and $\mathrm{PPh}_{2} \mathrm{H}$ were purchased from Strem Chemical, PhNCS, ICH ${ }_{2} \mathrm{CN}, \mathrm{BrCH}_{2} \mathrm{CH}=\mathrm{CH}_{2}, \mathrm{ICH}_{2} \mathrm{CONH}_{2}$, and $\mathrm{BrCH}_{2^{-}}$ $\mathrm{CO}_{2} \mathrm{Me}$ were purchased from Merck, and propargyl bromide, purchased al so from Merck, was distilled before use. W(CO) $\left(\mathrm{PPh}_{2} \mathrm{H}\right)(\mathbf{1 a})$ was prepared according to a literature method. ${ }^{8 a}$

(11) Snead, T. E.; Mirkin, C. A.; Lu, K. L.; Nguyen, S. T.; Feng, W C.; Beckman, H. L.; Geoffroy, G. L.; Rheingold, A. L.; Haggerty, B. S. Organometallics 1992, 11, 2613.

(12) (a) Moore, S. S.; Whitesides, G. M. J . Org. Chem. 1982, 47, 1489. (b) Al-Dulaymmi, M. F.; Hills, A.; Hitchcock, P. B.; Hughes, D. L.; Richards, R. J . Chem. Soc., Dalton Trans. 1992, 241. 
Preparation of $\mathbf{2 a}$. A solution of $\mathbf{1 a}(0.61 \mathrm{~g}, 1.20 \mathrm{mmol})$ in diethyl ether $(20 \mathrm{~mL})$ was treated with n-BuLi (1.6 M, 0.80 $\mathrm{mL}, 1.28 \mathrm{mmol}$ ) at $0{ }^{\circ} \mathrm{C}$, and the mixture was stirred for 5 min and slowly warmed to room temperature. To the mixture was added $0.15 \mathrm{~mL}$ of PhNCS $(1.30 \mathrm{mmol})$, and the solution was stirred for $10 \mathrm{~min}$. Addition of a solution of tetraethylammonium bromide $(0.32 \mathrm{~g}, 1.52 \mathrm{mmol}$ in $10 \mathrm{~mL}$ of methanol) to the mixture caused formation of a yellow precipitate, which was filtered, with $2 \times 10 \mathrm{~mL}$ of hexane, and then dried under vacuum to give $\left[\mathrm{Et}_{4} \mathrm{~N}\right]\left[\mathrm{W}(\mathrm{CO})_{5} \mathrm{PPh}{ }_{2} \mathrm{C}(=\mathrm{NPh}) \mathrm{S}\right](\mathbf{2 a} ; 0.79 \mathrm{~g}, 85 \%$ yield). Spectroscopic data for $\mathbf{2 a}$ are as follows. IR (THF): 2062 (m), 1963 (w), 1919 (vs). ${ }^{31} \mathrm{P}$ NMR $\left(\mathrm{CDCl}_{3}\right): \delta 34.3(\mathrm{~J} \mathrm{w}-\mathrm{P}$ $=238.9 \mathrm{~Hz}) .{ }^{1} \mathrm{H} \mathrm{NMR}\left(\mathrm{CDCl}_{3}\right): \delta 1.15\left(\mathrm{tt}, 12 \mathrm{H}, \mathrm{CH}_{3},{ }^{3} \mathrm{~J}_{\mathrm{N}-\mathrm{H}}=\right.$ 1.7, $\left.\mathrm{J} \mathrm{H}-\mathrm{H}^{2}=7.4 \mathrm{~Hz}\right), 3.08\left(\mathrm{q}, 8 \mathrm{H}, \mathrm{CH}_{2}, \mathrm{~J} \mathrm{H}-\mathrm{H}^{-}=7.4 \mathrm{~Hz}\right), 6.85-$ $7.77(\mathrm{~m}, 15 \mathrm{H}, \mathrm{Ph}) .{ }^{13} \mathrm{C} \mathrm{NMR}\left(\mathrm{CDCl}_{3}\right): \delta 7.3\left(\mathrm{CH}_{3}\right), 52.2\left(\mathrm{CH}_{2}\right)$, $121.3(\mathrm{~s}), 122.3(\mathrm{~s}), 127.4\left(\mathrm{~d},{ }^{3} \mathrm{p} \mathrm{p}-\mathrm{C}=8.7 \mathrm{~Hz}\right), 128.8(\mathrm{~s}), 129.8$ (s), $134.0\left(\mathrm{~d},{ }^{2} \mathrm{~J}_{\mathrm{p}-\mathrm{C}}=9.8 \mathrm{~Hz}\right), 134.9(\mathrm{~s}), 139.0(\mathrm{~d}, \mathrm{~J} \mathrm{p}-\mathrm{C}=35.7$ $\mathrm{Hz}), 190.3\left(\mathrm{~d}, \mathrm{CS}, \mathrm{J} \mathrm{p}-\mathrm{C}=29.3 \mathrm{~Hz}\right.$ ), $198.8\left(\mathrm{dd}, \mathrm{cis}-\mathrm{CO},{ }^{2} \mathrm{~J}-\mathrm{c}=\right.$ 6.8, J w-c $=123.8 \mathrm{~Hz}$ ), $201.9\left(\mathrm{~d}\right.$, trans-CO, ${ }^{2} \mathrm{~J} \mathrm{p}-\mathrm{C}=22.5 \mathrm{~Hz}$ ). MS: $\mathrm{m} / \mathrm{z} 774\left(\mathrm{M}^{+}+\mathrm{Et}_{4} \mathrm{~N}\right), 611\left(\mathrm{M}^{+}+\mathrm{Et}_{4} \mathrm{~N}-\mathrm{CO}-\mathrm{PhNCS}\right)$. Anal. Calcd for $\mathrm{C}_{32} \mathrm{H}_{35} \mathrm{O}_{5} \mathrm{~N}_{2} \mathrm{PSW}$ : $\mathrm{C}, 49.62 ; \mathrm{N}, 3.62 ; \mathrm{H}, 4.56$. Found: C, 49.54; N, 3.54; H, 4.23 .

Photodecarbonylation of $\mathbf{2 a}$. Complex $\mathbf{2 a}(0.14 \mathrm{~g}, 0.18$ $\mathrm{mmol}$ ) was dissolved in $10 \mathrm{~mL}$ of benzene, and the solution was photolyzed by UV radiation for $5 \mathrm{~min}$ at room temperature. The solvent was removed under vacuum, and the product was redissolved in $10 \mathrm{~mL}$ of $\mathrm{CH}_{2} \mathrm{Cl}_{2}$ /hexane (1/2). The mixture was stored at $-20{ }^{\circ} \mathrm{C}$ for $12 \mathrm{~h}$ to give the yellow crystalline product $\left[\mathrm{Et}_{4} \mathrm{~N}\right] \mathrm{W}(\mathrm{CO})_{4}\left[\eta^{2}-\mathrm{PPh}_{2} \mathrm{C}(=\mathrm{NPh}) \mathrm{S}\right](3 \mathrm{a} ; 0.09$ $\mathrm{g}, 68 \%$ yield). Spectroscopic data for $\mathbf{3 a}$ are as follows. IR (THF): 1987 (m), 1919 (m), 1871 (vs), 1819 (s) cm ${ }^{-1}$. 31P NMR $\left(\mathrm{CD}_{3} \mathrm{CN}\right): \delta 14.89(\mathrm{~J} \mathrm{w-p}=189.61 \mathrm{~Hz}) .{ }^{1} \mathrm{H} \mathrm{NMR}\left(\mathrm{CD}_{3} \mathrm{CN}\right): \delta$ $1.18\left(\mathrm{tt}, 12 \mathrm{H}, \mathrm{CH}_{3},{ }^{3} \mathrm{~J} \mathrm{~N}-\mathrm{H}=1.93 \mathrm{~Hz},{ }^{3} \mathrm{~J}_{\mathrm{H}-\mathrm{H}}=7.23 \mathrm{~Hz}\right), 3.12(\mathrm{q}$, $\left.8 \mathrm{H}, \mathrm{CH}_{2}, 3_{\mathrm{H}-\mathrm{H}}=7.25\right), 7.01-7.88(\mathrm{~m}, 15 \mathrm{H}, \mathrm{Ph}) .{ }^{13} \mathrm{C} \mathrm{NMR}$ $\left(\mathrm{CD}_{3} \mathrm{CN}\right): \delta 7.7\left(\mathrm{~s}, \mathrm{CH}_{3}\right), 53.0\left(\mathrm{~s}, \mathrm{CH}_{2}\right), 122.5(\mathrm{~s}), 124.4(\mathrm{~s}), 129.2$ $(\mathrm{d}, 3 \mathrm{~J}-\mathrm{C}=9.1 \mathrm{~Hz}$ ), $129.5(\mathrm{~s}), 131.0(\mathrm{~s}), 135.8(\mathrm{~d}, \mathrm{~J} \mathrm{p}-\mathrm{C}=26.0$ $\mathrm{Hz}), 133.9\left(\mathrm{~d},{ }^{2} \mathrm{~J} p-\mathrm{c}=12.3 \mathrm{~Hz}\right), 150.4(\mathrm{~d}, 3 \mathrm{~J} \mathrm{p}-\mathrm{c}=16.9 \mathrm{~Hz})$, $189.2(\mathrm{~d}, \mathrm{CS}$, J $\mathrm{p}-\mathrm{C}=42.8 \mathrm{~Hz}), 205.7$ (d, 2C, cis-CO, 2J $\mathrm{p}-\mathrm{C}=$ $7.3 \mathrm{~Hz}), 213.5\left(\mathrm{~d}, 1 \mathrm{C}\right.$, cis-CO, $\left.{ }^{2} \mathrm{p}-\mathrm{C}=7.3 \mathrm{~Hz}\right), 215.8$ (d, trans$\left.C O,{ }^{2}{ }_{p-C}=29.1 \mathrm{~Hz}\right) . M S: m / z 876\left(\mathrm{M}^{+}+\mathrm{Et}_{4} \mathrm{~N}\right), 848\left(\mathrm{M}^{+}+\right.$ $\left.\mathrm{Et}_{4} \mathrm{~N}-\mathrm{CO}\right)$. Anal. Calcd for $\mathrm{C}_{31} \mathrm{H}_{35} \mathrm{O}_{4} \mathrm{~N}_{2} \mathrm{PSW}$ : C, 49.88; $\mathrm{N}$, 3.75; $\mathrm{H}, 4.73$. Found: $\mathrm{C}, 49.77 ; \mathrm{N}, 3.71 ; \mathrm{H}, 5.01$.

Preparation of $\mathbf{3 b}$. A solution of $\mathrm{W}(\mathrm{CO})_{5}\left(\mathrm{PPh}_{2} \mathrm{H}\right)(\mathbf{1 a} ; 0.61$ $\mathrm{g}, 1.20 \mathrm{mmol})$ in diethyl ether $(20 \mathrm{~mL})$ was treated with $\mathrm{n}-\mathrm{BuLi}$ (1.6 M, $0.80 \mathrm{~mL}, 1.28 \mathrm{mmol}$ ) at $0{ }^{\circ} \mathrm{C}$, and the mixture was stirred for $5 \mathrm{~min}$ and slowly warmed to room temperature. To the mixture was added $0.17 \mathrm{~mL}$ of EtOC(O)NCS $(1.45 \mathrm{mmol})$, and the solution was stirred for $10 \mathrm{~min}$. Addition of a solution of tetraethylammonium bromide $(0.32 \mathrm{~g}, 1.52 \mathrm{mmol}$ in $10 \mathrm{~mL}$ of methanol) to the mixture caused formation of a yellow precipitate, which was filtered and washed with $2 \times 10 \mathrm{~mL}$ of hexane to give $\left[\mathrm{Et}_{4} \mathrm{~N}\right] \mathrm{W}(\mathrm{CO})_{4}\left[\eta^{2}-\mathrm{PPh}_{2} \mathrm{C}\left(=\mathrm{NCO}_{2} \mathrm{Et}\right) \mathrm{S}\right](3 \mathrm{~b})(0.42$ $\mathrm{g}, 47 \%$ yield). Single crystals of $\mathbf{3 b}$ can be obtained by recrystallization from a mixture of $1 / 1 \mathrm{CH}_{2} \mathrm{Cl}_{2} /$ hexane. Spectroscopic data for $\mathbf{3 b}$ are as follows. IR $\left(\mathrm{CH}_{2} \mathrm{Cl}_{2}\right)$ : $2003(\mathrm{~m})$, 1993 (m), 1877 (vs), 1817 (s) cm ${ }^{-1}$. 31P NMR (CDCl 3 ): $\delta 16.4$ $(\mathrm{J} w-\mathrm{p}=193.8 \mathrm{~Hz}) .{ }^{1} \mathrm{H}$ NMR $\left(\mathrm{CDCl}_{3}\right): \delta 1.22\left(\mathrm{tt}, 12 \mathrm{H}, \mathrm{CH}_{3}\right.$ 3 $\left.\mathrm{N}-\mathrm{H}=1.8,3 \mathrm{~J}_{\mathrm{H}-\mathrm{H}}=7.3 \mathrm{~Hz}\right), 1.29\left(\mathrm{t}, 3 \mathrm{H}, \mathrm{CH}_{3}, 3 \mathrm{~J}_{\mathrm{H}-\mathrm{H}}=7.3\right.$ $\mathrm{Hz}), 3.18\left(\mathrm{q}, 8 \mathrm{H}, \mathrm{CH}_{2},{ }^{3} \mathrm{~J} \mathrm{H}-\mathrm{H}^{2}=7.3 \mathrm{~Hz}\right), 4.16\left(\mathrm{q}, 2 \mathrm{H}, \mathrm{CH}_{2}, 3 \mathrm{~J} \mathrm{H}-\mathrm{H}\right.$ $=7.3 \mathrm{~Hz}), 7.35-7.78(\mathrm{~m}, 10 \mathrm{H}, \mathrm{Ph}) .{ }^{13} \mathrm{C} \mathrm{NMR}\left(\mathrm{CDCl}_{3}\right): \delta 7.6$ $\left(\mathrm{s}, \mathrm{NCH}_{2} \mathrm{CH}_{3}\right), 14.6\left(\mathrm{~s}, \mathrm{OCH}_{2} \mathrm{CH}_{3}\right), 52.6\left(\mathrm{t}, \mathrm{NCH}_{2}, \mathrm{~J}\right.$ N-C $=2.8$ $\mathrm{Hz}), 62.1\left(\mathrm{~s}, \mathrm{OCH}_{2}\right), 128.3$ (d, 3 $\left.\mathrm{p}-\mathrm{C}=9.1 \mathrm{~Hz}\right), 130.1$ (s), 133.5 $\left(d, J p-c=26.8 \mathrm{~Hz}\right.$ ), $133.2\left(d,{ }^{2} \mathrm{~J}-\mathrm{C}=13.2 \mathrm{~Hz}\right), 197.6$ (d, CS, $\left.\mathrm{J}_{\mathrm{p}-\mathrm{C}}=32.9 \mathrm{~Hz}\right), 204.5\left(\mathrm{~d}, 2 \mathrm{C}\right.$, cis-CO, $\left.\mathrm{J}_{\mathrm{p}-\mathrm{C}}=7.3 \mathrm{~Hz}\right), 212.3$ (d, 1C, cis-CO, $\left.{ }^{2} \mathrm{~J}-\mathrm{C}=7.8 \mathrm{~Hz}\right), 214.9\left(\mathrm{~d}\right.$, trans-CO, ${ }^{2} \mathrm{~J}_{\mathrm{p}-\mathrm{C}}=$ $29.6 \mathrm{~Hz})$. MS: $\mathrm{m} / \mathrm{z} 872\left(\mathrm{M}^{+}+2 \mathrm{Et}_{4} \mathrm{~N}\right), 844\left(\mathrm{M}^{+}+2 \mathrm{Et}_{4} \mathrm{~N}-\right.$ $\mathrm{CO}), 816\left(\mathrm{M}^{+}+2 \mathrm{Et}_{4} \mathrm{~N}-2 \mathrm{CO}\right)$. Anal. Calcd for $\mathrm{C}_{28} \mathrm{H}_{35} \mathrm{O}_{6} \mathrm{~N}_{2-}$ PSW: C, 45.29; N, 3.77; H, 4.75. Found: C, 46.79; N, 4.01; $\mathrm{H}, 4.51$.

Preparation of 6. To a solution of $\mathbf{2 a}(0.79 \mathrm{~g}, 1.02 \mathrm{mmol})$ in $\mathrm{CH}_{3} \mathrm{CN}(40 \mathrm{~mL})$ was added $\mathrm{ICH}_{2} \mathrm{CONH}_{2}(0.20 \mathrm{~g}, 1.10 \mathrm{mmol})$ at room temperature, the sol ution was stirred for $10 \mathrm{~min}$, and then the solvent was removed under vacuum. The residue was extracted with $2 \times 20 \mathrm{~mL}$ of diethyl ether. After filtration, the volume of the sol ution was reduced to about $8 \mathrm{~mL}$ and the solution was stored at $-20^{\circ} \mathrm{C}$ to yield a crystalline solid, which was filtered and dried under vacuum to give $\mathrm{W}(\mathrm{CO})_{5} \mathrm{PPh}_{2} \mathrm{C}$ (=NPh)SCH${ }_{2} \mathrm{CONH}_{2}(6 ; 0.57 \mathrm{~g}, 80 \%$ yield). Spectroscopic data for 6 are as follows. IR (KBr): 2070 (s), 1934 (vs) $\mathrm{cm}^{-1}$. ${ }^{31} \mathrm{P}$ $\mathrm{NMR}\left(\mathrm{CDCl}_{3}\right): \delta 38.0(\mathrm{~J} \mathrm{w}-\mathrm{P}=244.6 \mathrm{~Hz}) .{ }^{1} \mathrm{H} \mathrm{NMR}\left(\mathrm{CDCl}_{3}\right)$ : $\delta 2.98\left(\mathrm{~s}, 2 \mathrm{H}, \mathrm{SCH}_{2}\right), 5.33\left(\mathrm{br}, 1 \mathrm{H}, \mathrm{NH}_{2}\right), 5.52\left(\mathrm{br}, 1 \mathrm{H}, \mathrm{NH}_{2}\right)$, 6.97-7.74 (m, $15 \mathrm{H}, \mathrm{Ph}) .{ }^{13} \mathrm{C} \mathrm{NMR}\left(\mathrm{CDCl}_{3}\right): \delta 36.0\left(\mathrm{~d}, \mathrm{SCH}_{2}\right.$ 3) $\left.{ }_{P-C}=1.9 \mathrm{~Hz}\right), 119.0(\mathrm{~s}), 125.4(\mathrm{~s}), 128.7\left(\mathrm{~d}, 3^{3} \mathrm{P}-\mathrm{C}=9.8 \mathrm{~Hz}\right)$, 129.5 (s), 131.0 (s), 132.9 (d, J p-c $=40.6 \mathrm{~Hz}$ ), 133.6 (d, '2 $\mathrm{p}-\mathrm{c}$ $=11.7 \mathrm{~Hz}), 147.3\left(\mathrm{~d}, 3_{\mathrm{p}-\mathrm{C}}=15.5 \mathrm{~Hz}\right), 163.1\left(\mathrm{~d}, \mathrm{CS}, \mathrm{J}_{\mathrm{p}-\mathrm{C}}=\right.$ $45.0 \mathrm{~Hz}$ ), 168.5 (s, CO), 196.6 (d, cis-CO, 2 J p-c $=6.6 \mathrm{~Hz}), 198.7$ $\left(\mathrm{d}\right.$, trans-CO, $\left.{ }^{2} \mathrm{P}-\mathrm{C}=24.0 \mathrm{~Hz}\right)$. MS: $\mathrm{m} / \mathrm{z} 702\left(\mathrm{M}^{+}\right), 674\left(\mathrm{M}^{+}\right.$ - CO), $646\left(\mathrm{M}^{+}-2 \mathrm{CO}\right), 618\left(\mathrm{M}^{+}-3 \mathrm{CO}\right), 590\left(\mathrm{M}^{+}-4 \mathrm{CO}\right)$, $562\left(\mathrm{M}^{+}-5 \mathrm{CO}\right), 504\left(\mathrm{M}^{+}-5 \mathrm{CO}-\mathrm{CH}_{2} \mathrm{CONH}_{2}\right)$. Anal. Calcd for $\mathrm{C}_{26} \mathrm{H}_{19} \mathrm{~N}_{2} \mathrm{O}_{6} \mathrm{PSW}$ : C, 44.46; N, 3.99; $\mathrm{H}, 2.73$. Found: $\mathrm{C}$, 45.21; N , 4.16; $\mathrm{H}, 3.02$. $\mathrm{W}(\mathrm{CO})_{5} \mathrm{PPh}_{2} \mathrm{C}(=\mathrm{NPh}) \mathrm{SCH}_{2} \mathrm{C} \equiv \mathrm{CH}(4)$, $\mathrm{W}(\mathrm{CO})_{5} \mathrm{PPh}_{2} \mathrm{C}(=\mathrm{NPh}) \mathrm{SCH}_{2} \mathrm{C} \equiv \mathrm{N} \quad(5), \mathrm{W}(\mathrm{CO})_{5} \mathrm{PPh}_{2} \mathrm{C}(=\mathrm{NPh})-$ $\mathrm{SCH}_{2} \mathrm{CH}=\mathrm{CH}_{2}$ (7), and $\mathrm{W}(\mathrm{CO})_{5} \mathrm{PPh}_{2} \mathrm{C}(=\mathrm{NPh}) \mathrm{SCH}_{2} \mathrm{CO}_{2} \mathrm{Me}(8)$ were synthesized using the same procedure as that used in the synthesis of $\mathbf{6}$ by employing $\mathbf{2} \mathbf{a}$ and the corresponding halides $\mathrm{BrCH}_{2} \mathrm{C} \equiv \mathrm{CH}, I \mathrm{CH}_{2} \mathrm{C} \equiv \mathrm{N}, \mathrm{BrCH}_{2} \mathrm{CH}=\mathrm{CH}_{2}$, and $\mathrm{BrCH}_{2-}$ $\mathrm{CO}_{2} \mathrm{Me}$, respectively. The yields are $84 \%, 88 \%, 86 \%$, and $75 \%$ for $\mathbf{4}, \mathbf{5}, \mathbf{7}$, and $\mathbf{8}$, respectively.

Spectroscopic data for 4 are as follows. IR $\left(\mathrm{CH}_{2} \mathrm{Cl}_{2}\right): 2073$ (m), 1934 (vs) cm ${ }^{-1}$. ${ }^{31} \mathrm{P} \mathrm{NMR}\left(\mathrm{CDCl}_{3}\right): \delta 38.03(\mathrm{~J} \mathrm{w-P}=246.8$ $\mathrm{Hz})$. ${ }^{1} \mathrm{H} N M R\left(\mathrm{CDCl}_{3}\right): \delta 2.04\left(\mathrm{t}, 1 \mathrm{H}, \mathrm{CH},{ }^{4} \mathrm{H}-\mathrm{H}=1.80 \mathrm{~Hz}\right)$ $2.88\left(\mathrm{~d}, 2 \mathrm{H}, \mathrm{S}-\mathrm{CH}_{2}, 4 \mathrm{H}-\mathrm{H}=1.80 \mathrm{~Hz}\right), 7.04-7.74(\mathrm{~m}, 15 \mathrm{H}, \mathrm{Ph})$. ${ }^{13} \mathrm{C} \mathrm{NMR}\left(\mathrm{CDCl}_{3}\right): \delta 1.64\left(\mathrm{~S}-\mathrm{CH}_{2}\right), 72.82(\equiv \mathrm{CH}), 77.82$ $(\mathrm{C} \equiv \mathrm{CH}), 118.92(\mathrm{~s}), 125.1(\mathrm{~s}), 128.52\left(\mathrm{~d},{ }^{3} \mathrm{~J} \mathrm{p}-\mathrm{C}=7.5 \mathrm{~Hz}\right), 129.21$ (s), 132.8 (s), 133.66 (d, 2J $p-c=11.3 \mathrm{~Hz}), 132.84$ (s), 147.73 $\left(d, J_{P-C}=18.0 \mathrm{~Hz}\right.$ ), $162.92\left(\mathrm{~d}, \mathrm{CS}, \mathrm{J}_{\mathrm{P}-\mathrm{C}}=51.2 \mathrm{~Hz}\right.$ ), 196.70 (dd, cis-CO, 2J p-c = 7.5, J w-c $=127.5 \mathrm{~Hz}), 199.12$ (d, trans$\left.\mathrm{CO},{ }^{2} \mathrm{~J} \mathrm{P}_{-\mathrm{C}}=24.0 \mathrm{~Hz}\right) . \mathrm{MS}: \mathrm{m} / \mathrm{z} 683\left(\mathrm{M}^{+}\right), 655\left(\mathrm{M}^{+}-\mathrm{CO}\right)$. Anal. Calcd for $\mathrm{C}_{27} \mathrm{H}_{18} \mathrm{NO}_{5} \mathrm{PSW}$ : C, 47.46; N, 2.05; $\mathrm{H}, 2.66$. Found: C, 48.22; N, 2.31; H, 2.94.

Spectroscopic data for 5 are as follows. IR $\left(\mathrm{CH}_{2} \mathrm{Cl}_{2}\right): 2073$ (m), 1936 (vs) cm ${ }^{-1}$. ${ }^{31} \mathrm{P} \mathrm{NMR}\left(\mathrm{CDCl}_{3}\right): \delta 38.72(\mathrm{~J} \mathrm{w}-\mathrm{P}=247.4$ $\mathrm{Hz}) .{ }^{1} \mathrm{H} N M R\left(\mathrm{CDCl}_{3}\right): \delta 2.97\left(\mathrm{~s}, 2 \mathrm{H}, \mathrm{CH}_{2}\right), 7.04-7.74(\mathrm{~m}, 15 \mathrm{H}$, $\mathrm{Ph}) .{ }^{13} \mathrm{C} \mathrm{NMR}\left(\mathrm{CDCl}_{3}\right): \delta 17.81\left(\mathrm{CH}_{2}\right), 114.6(\mathrm{CN}), 118.86(\mathrm{~s})$, $125.76(\mathrm{~s}), 128.77(\mathrm{~d}, 3 \mathrm{~J} \mathrm{p}-\mathrm{c}=9.8 \mathrm{~Hz}), 129.59(\mathrm{~s}), 131.19(\mathrm{~s})$, $133.59\left(\mathrm{~d}, \mathrm{~J}_{\mathrm{P}-\mathrm{C}}=8.3 \mathrm{~Hz}\right), 134.92(\mathrm{~s}), 146.72(\mathrm{~d}, \mathrm{~J} \mathrm{p}-\mathrm{C}=15.0$ $\mathrm{Hz}), 160.92(\mathrm{~d}, \mathrm{CS}, \mathrm{J} \mathrm{p}-\mathrm{C}=48.5 \mathrm{~Hz}), 196.43$ (d, cis-CO, ${ }^{2} \mathrm{~J}-\mathrm{c}=$ $6.8 \mathrm{~Hz}), 198.50\left(\mathrm{~d}\right.$, trans-CO, $\left.{ }^{2} \mathrm{~J}-\mathrm{c}=24.8 \mathrm{~Hz}\right) . \quad$ MS: $\mathrm{m} / \mathrm{z} 684$ $\left(\mathrm{M}^{+}\right), 656\left(\mathrm{M}^{+}-\mathrm{CO}\right), 544\left(\mathrm{M}^{+}-5 \mathrm{CO}\right)$. Anal. Calcd for $\mathrm{C}_{26^{-}}$ $\mathrm{H}_{17} \mathrm{~N}_{2} \mathrm{O}_{5} \mathrm{PSW}$ : C, 45.63; N, 4.09; $\mathrm{H}, 2.50$. Found: $\mathrm{C}, 45.92$; $\mathrm{N}, 4.11 ; \mathrm{H}, 2.97$.

Spectroscopic data for $\mathbf{7}$ are as follows. IR $\left(\mathrm{CH}_{3} \mathrm{CN}\right): 2072$ (m), 1931 (vs) cm ${ }^{-1}$. ${ }^{31} \mathrm{P} \mathrm{NMR}\left(\mathrm{CDCl}_{3}\right): \delta 39.13(\mathrm{~J} \mathrm{w}-\mathrm{P}=244.4$ $\mathrm{Hz}) .{ }^{1} \mathrm{H} \mathrm{NMR}\left(\mathrm{CDCl}_{3}\right): \delta 2.87\left(\mathrm{~d}, 2 \mathrm{H}, \mathrm{SCH}_{2}, \mathrm{~J} \mathrm{H}-\mathrm{H}=6.8 \mathrm{~Hz}\right)$, $4.76\left(\mathrm{dd}, 1 \mathrm{H},=\mathrm{CH}, \mathrm{J}_{\mathrm{H}-\mathrm{H}}=16.9,1.2 \mathrm{~Hz}\right), 4.83(\mathrm{~d}, 1 \mathrm{H},=\mathrm{CH}$, $\left.\mathrm{J}_{\mathrm{H}-\mathrm{H}}=9.5 \mathrm{~Hz}\right), 5.22(\mathrm{~m}, 1 \mathrm{H},=\mathrm{CH}), 7.07-7.76(\mathrm{~m}, 15 \mathrm{H}, \mathrm{Ph})$. MS: $\mathrm{m} / \mathrm{z} 685\left(\mathrm{M}^{+}\right), 657\left(\mathrm{M}^{+}-\mathrm{CO}\right), 601\left(\mathrm{M}^{+}-3 \mathrm{CO}\right), 573\left(\mathrm{M}^{+}\right.$ $-4 \mathrm{CO}), 545\left(\mathrm{M}^{+}-5 \mathrm{CO}\right), 504\left(\mathrm{M}^{+}-5 \mathrm{CO}-\mathrm{C}_{3} \mathrm{H}_{5}\right)$. Anal. Calcd for $\mathrm{C}_{27} \mathrm{H}_{20} \mathrm{O}_{5} \mathrm{NPSW}$ : C, 47.32; $\mathrm{N}, 2.04 ; \mathrm{H}, 2.94$. Found: $\mathrm{C}$, 48.01; N, 2.25; H, 3.11.

Spectroscopic data for 8 are as follows. IR $\left(\mathrm{CH}_{3} \mathrm{CN}\right): 2073$ (m), 1935 (vs) cm ${ }^{-1}$. ${ }^{31} \mathrm{P} \mathrm{NMR}\left(\mathrm{CDCl}_{3}\right): \delta 38.17(\mathrm{~J} \mathrm{w}-\mathrm{P}=248.8$ $\mathrm{Hz}) .{ }^{1} \mathrm{H} \mathrm{NMR}\left(\mathrm{CDCl}_{3}\right): \delta 3.07\left(\mathrm{~s}, 2 \mathrm{H}, \mathrm{SCH}_{2}\right), 3.48\left(\mathrm{~s}, 3 \mathrm{H}, \mathrm{CH}_{3}\right)$, 6.97-7.75 (m, 15H, Ph). MS: $\mathrm{m} / \mathrm{z} 717\left(\mathrm{M}^{+}\right), 689\left(\mathrm{M}^{+}-\mathrm{CO}\right)$, $633\left(\mathrm{M}^{+}-3 \mathrm{CO}\right), 605\left(\mathrm{M}^{+}-4 \mathrm{CO}\right), 532\left(\mathrm{M}^{+}-4 \mathrm{CO}-\mathrm{CH}_{2-}\right.$ $\mathrm{CO}_{2} \mathrm{CH}_{3}$ ). Anal. Calcd for $\mathrm{C}_{27} \mathrm{H}_{20} \mathrm{O}_{7} \mathrm{NPSW}$ : C, 45.21; N, 1.95; $\mathrm{H}, 2.81$. Found: $\mathrm{C}, 45.79 ; \mathrm{N}, 2.15 ; \mathrm{H}, 2.99$.

Protonation of 4. To a solution of complex $4(0.79 \mathrm{~g}, 1.16$ $\mathrm{mmol})$ in $10 \mathrm{~mL}$ of hexane was slowly added $\mathrm{HBF}_{4}(0.25 \mathrm{~mL}$ of a $54 \%$ solution in ether, $1.23 \mathrm{mmol}$ ) at $0{ }^{\circ} \mathrm{C}$. The mixture was stirred for $5 \mathrm{~min}$ at $0{ }^{\circ} \mathrm{C}$ and slowly warmed to room temperature. A precipitate formed, which was filtered and 
Table 1. Crystal and Intensity Collection Data for $\mathrm{W}(\mathrm{CO})_{5}\left[\mathrm{PPh}_{2} \mathrm{CSCH}_{2} \mathrm{C}\left(\mathrm{CH}_{2}\right) \mathrm{NPh}_{\mathrm{BBF}} \mathrm{C}_{4}(10)\right.$ and

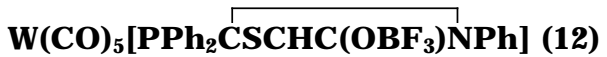

\begin{tabular}{|c|c|c|}
\hline mol formula & $\begin{array}{l}\mathrm{C}_{27} \mathrm{H}_{19} \mathrm{O}_{5} \mathrm{NSPWBF}_{4} \\
\text { (10) }\end{array}$ & $\begin{array}{l}\mathrm{C}_{27} \mathrm{H}_{18} \mathrm{O}_{6} \mathrm{NSCl}_{2} \mathrm{PWBF}_{3} \\
(\mathbf{1 2})^{\mathrm{a}}\end{array}$ \\
\hline space group & $\mathrm{P} \overline{1}$ & $\mathrm{P} \overline{1}$ \\
\hline$a, \AA$ & $8.905(5)$ & $9.3967(10)$ \\
\hline$b, \AA$ & $10.437(4)$ & $10.6208(13)$ \\
\hline c, $\AA$ & $17.044(4)$ & $16.7676(12)$ \\
\hline$\alpha$, deg & $85.84(3)$ & $76.979(8)$ \\
\hline$\beta$, deg & $83.32(4)$ & $86.792(7)$ \\
\hline$\gamma$, deg & $83.78(4)$ & $72.73(9)$ \\
\hline $\mathrm{V}, \AA^{3}$ & 1419.2(11) & $1556.8(3)$ \\
\hline Z & 2 & 2 \\
\hline $\begin{array}{l}\text { cryst dimens, } \mathrm{mm} \\
\text { radiation }\end{array}$ & $\begin{array}{r}0.10 \times 0.40 \times 0.45 \\
\operatorname{MoK} \alpha, \lambda\end{array}$ & $\begin{array}{l}0.30 \times 0.30 \times 0.40 \\
=0.7107 \AA\end{array}$ \\
\hline $2 \theta$ range, deg & & -50 \\
\hline scan type & & $\theta / 2 \theta$ \\
\hline total no. of rflns & 4999 & 5458 \\
\hline $\begin{array}{l}\text { no. of unique rflns, } \\
\qquad \mid>2 \sigma(I)\end{array}$ & 4162 & 4839 \\
\hline $\mathrm{R}, \mathrm{R}_{\mathrm{w}}(\mathrm{I}>2 \sigma(\mathrm{I}))$ & $0.053,0.055$ & $0.023,0.018$ \\
\hline $\mathrm{R}, \mathrm{R}_{\mathrm{w}}$ (all data) & $0.068,0.056$ & $0.029,0.018$ \\
\hline
\end{tabular}

washed with $2 \times 20 \mathrm{~mL}$ of hexane to give the crude product, which was further purified by recrystallization from $\mathrm{CH}_{2} \mathrm{Cl}_{2} /$ hexane (2/1) to give W(CO) $)_{5} \mathrm{Ph}_{2}\left[\mathrm{CSCH}_{2} \mathrm{C}\left(\mathrm{CH}_{2}\right) \mathrm{NPh}_{\mathrm{BF}}\right.$ (10; $0.58 \mathrm{~g}, 65 \%)$. Spectroscopic data for $\mathbf{1 0}$ are as fol lows. IR $\left(\mathrm{CH}_{2^{-}}\right.$ $\left.\mathrm{Cl}_{2}\right): 2077(\mathrm{~m}), 1941(\mathrm{~s}) \mathrm{cm}^{-1}$. ${ }^{31} \mathrm{P}$ NMR $\left(\mathrm{C}_{2} \mathrm{D}_{6} \mathrm{CO}\right): \delta 41.42$ $(\mathrm{w}-\mathrm{p}=254.2 \mathrm{~Hz}) .{ }^{1} \mathrm{H} N M R\left(\mathrm{C}_{2} \mathrm{D}_{6} \mathrm{CO}\right): \delta 4.68\left(\mathrm{~m}, 1 \mathrm{H},=\mathrm{CH}_{2}\right)$, $5.11\left(\mathrm{~m}, 2 \mathrm{H}, \mathrm{CH}_{2}\right), 5.65\left(\mathrm{~m}, 1 \mathrm{H},=\mathrm{CH}_{2}\right), 6.93-7.53(\mathrm{~m}, 15 \mathrm{H}$, $\mathrm{Ph}) .{ }^{13} \mathrm{C} N M R\left(\mathrm{C}_{2} \mathrm{D}_{6} \mathrm{CO}\right): \delta 74.06\left(\mathrm{CH}_{2}\right), 118-135(\mathrm{~m}, \mathrm{Ph})$, 163.45 (d, CS, J p-c = 25.2 Hz), 196.02 (br, cis-CO), 196.81 (d, trans-CO, 2 $\mathrm{p}-\mathrm{C}=7.5 \mathrm{~Hz}) . \quad \mathrm{MS}: \mathrm{m} / \mathrm{z} 684\left(\mathrm{M}^{+}-\mathrm{BF}_{4}\right), 628$ $\left(\mathrm{M}^{+}-\mathrm{BF}_{4}-2 \mathrm{CO}\right)$. Anal. Calcd for $\mathrm{C}_{27} \mathrm{H}_{19} \mathrm{BF}_{4} \mathrm{NO}_{5} \mathrm{PSW}$ : C, 42.05; N, 3.63; H, 2.48. Found: C, 41.77; N, 3.53; H, 3.10.

Protonation of $5(0.92 \mathrm{~g}, 1.34 \mathrm{mmol})$ was similarly carried out in hexane to give $\left[\mathrm{W}(\mathrm{CO})_{5} \mathrm{PPh}_{2} \mathrm{CSCHC}\left(\mathrm{NH}_{2}\right) \mathrm{NPh}_{\mathrm{BF}}\right.$ ( $\mathbf{1 1}$; $0.67 \mathrm{~g}$ ) in $65 \%$ yield. Spectroscopic data for $\mathbf{1 1}$ are as follows. IR $\left(\mathrm{CH}_{2} \mathrm{Cl}_{2}\right): 2079(\mathrm{~m}), 1941$ (vs) $\mathrm{cm}^{-1}$. ${ }^{31} \mathrm{P}$ NMR $\left(\mathrm{C}_{2} \mathrm{D}_{6} \mathrm{CO}\right)$ : $\delta 18.89(\mathrm{~W}-\mathrm{p}=256.5 \mathrm{~Hz}) .{ }^{1} \mathrm{H}$ NMR $\left(\mathrm{C}_{2} \mathrm{D}_{6} \mathrm{CO}\right): \delta 6.02(\mathrm{br}$, $\left.\mathrm{NH}_{2}\right), 6.22(\mathrm{br}, 1 \mathrm{H}, \mathrm{CH}), 6.85-7.60(\mathrm{~m}, 15 \mathrm{H}, \mathrm{Ph}) .{ }^{13} \mathrm{C} \mathrm{NMR}$ $\left(\mathrm{C}_{2} \mathrm{D}_{6} \mathrm{CO}\right): \delta 102.67\left(\mathrm{~d},=\mathrm{C},{ }^{3} \mathrm{P}-\mathrm{C}=5.5 \mathrm{~Hz}\right), 127-133(\mathrm{~m}, \mathrm{Ph})$, $158.76\left(\mathrm{~s}, \mathrm{CNH}_{2}\right), 160.88$ (br, CS), 196.91 (br, cis-CO), 198.56 (d, trans-CO, $\left.{ }^{2} \mathrm{f}-\mathrm{C}=32.0 \mathrm{~Hz}\right)$. MS: $\mathrm{m} / \mathrm{z} 685\left(\mathrm{M}^{+}-\mathrm{BF}_{4}\right)$, $601\left(\mathrm{M}^{+}-\mathrm{BF}_{4}-3 \mathrm{CO}\right), 573\left(\mathrm{M}^{+}-\mathrm{BF}_{4}-4 \mathrm{CO}\right), 545\left(\mathrm{M}^{+}-\right.$ $\mathrm{BF}_{4}-5 \mathrm{CO}$ ). Anal. Calcd for $\mathrm{C}_{26} \mathrm{H}_{18} \mathrm{BF}_{4} \mathrm{~N}_{2} \mathrm{O}_{5} \mathrm{PSW}$ : C, 40.44; $H, 2.35$. Found: $C, 40.71 ; H, 2.83$.

Protonation of 6. An aliquot of $\mathrm{HBF}_{4}(0.22 \mathrm{~mL}, 1.10$ $\mathrm{mmol})$ was added at room temperature to complex $6(0.70 \mathrm{~g}$, $1.0 \mathrm{mmol}$ ) dissolved in $40 \mathrm{~mL}$ of diethyl ether. The solution was stirred for $10 \mathrm{~min}$, and then the solvent was removed under vacuum. The residue was washed with $2 \times 10 \mathrm{~mL}$ of hexane, and the product was purified by recrystallization from $\mathrm{CH}_{2} \mathrm{Cl}_{2} /$ hexane (2/1) to give W(CO) $)_{5} \mathrm{PPh}_{2} \mathrm{CSCHC}\left(\mathrm{OBF}_{3}\right) \mathrm{NPh}$ (12; $0.54 \mathrm{~g}, 72 \%$ yield). Spectroscopic data for $\mathbf{1 2}$ are as follows. IR (KBr): 2076 (s), 1920 (vs), (CN) $1579 \mathrm{~cm}^{-1}$. ${ }^{31} \mathrm{P}$ NMR $\left(\mathrm{CDCl}_{3}\right): \delta 23.47(\mathrm{~J}-\mathrm{p}=261.7 \mathrm{~Hz}) .{ }^{1} \mathrm{H} \mathrm{NMR}\left(\mathrm{CDCl}_{3}\right): \delta 7.26$ (1H), 6.4-7.6 (m, 15H, Ph). ${ }^{13} \mathrm{C} \mathrm{NMR}\left(\mathrm{CDCl}_{3}\right): \delta 101.1(\mathrm{~s}, \mathrm{CH})$, 127.1 (s, m-C of Ph), 129.47 (s, p-C of Ph), 129.5 (d, m-C of Ph, ${ }^{3} \mathrm{p}-\mathrm{C}=10.6 \mathrm{~Hz}$ ), $130.9(\mathrm{~s}, \mathrm{p}-\mathrm{C}$ of Ph), $132.0(\mathrm{~s}, \mathrm{o}-\mathrm{C}$ of Ph), 130.4 (d, ipso C of Ph, J P-C $=44.4 \mathrm{~Hz}$ ), $131.7\left(\mathrm{~d}, \mathrm{o}-\mathrm{C}\right.$ of $\mathrm{Ph},{ }^{2} \mathrm{~J}-\mathrm{C}=$ 12.9 Hz), 133.7 (s, ipso C of Ph), 159.1 (s, COB), 162.7 (s, PCN), 195.5 (d, cis-CO, 2) p-c = 6.3 Hz), 196.7 (d, trans-CO, 2) p-c = $25.9 \mathrm{~Hz}) .{ }^{19} \mathrm{~F} \mathrm{NMR}\left(\mathrm{CDCl}_{3}\right):-154.70(\mathrm{~s}),-154.76(\mathrm{~s}) . \mathrm{MS}:$ $\mathrm{m} / \mathrm{z} 773\left(\mathrm{M}^{+}+\mathrm{HF}\right), 689\left(\mathrm{M}^{+}+\mathrm{HF}-3 \mathrm{CO}\right), 661\left(\mathrm{M}^{+}+\mathrm{HF}-\right.$ 4CO). Anal. Calcd for $\mathrm{C}_{26} \mathrm{H}_{16} \mathrm{BNF}_{3} \mathrm{O}_{6} \mathrm{PSW}$ : C, 41.46; N, 1.86; $\mathrm{H}, 2.14$. Found: $\mathrm{C}, 40.96 ; \mathrm{N}, 1.88 ; \mathrm{H}, 2.40$.
Table 2. Selected Interatomic Distances $(\mathcal{A})$ and Bond Angles (deg) of the

W(CO) $)_{5}\left[\mathrm{PPh}_{2} \mathrm{CSCH}_{2} \mathrm{C}\left(\mathrm{CH}_{2}\right) \mathrm{NPh}\right]$ Cation and

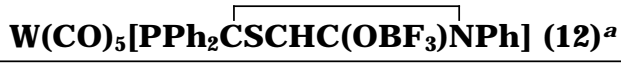

\begin{tabular}{|c|c|c|c|}
\hline \multicolumn{2}{|c|}{ cation of $\mathbf{1 0}$} & \multicolumn{2}{|c|}{12} \\
\hline $\begin{array}{l}W-P \\
W-C(1) \\
W-C(2) \\
W-C(3) \\
W-C(4) \\
W-C(5) \\
P-C(6) \\
P-C(16) \\
P-C(22) \\
S-C(6) \\
S-C(7) \\
C(1)-O(1) \\
C(2)-O(2) \\
C(3)-O(3) \\
C(4)-O(4) \\
C(5)-O(5) \\
C(6)-N \\
C(7)-C(8) \\
C(8)-C(9) \\
C(8)-N \\
C(10)-N\end{array}$ & $\begin{array}{l}2.532(3) \\
1.999(11) \\
1.998(10) \\
1.995(11) \\
2.034(12) \\
2.000(10) \\
1.860(10) \\
1.830(9) \\
1.829(9) \\
1.700(9) \\
1.808(11) \\
1.163(14) \\
1.165(13) \\
1.129(13) \\
1.131(15) \\
1.155(12) \\
1.312(11) \\
1.497(14) \\
1.307(15) \\
1.448(12) \\
1.455(11)\end{array}$ & $\begin{array}{l}\text { W-P } \\
\text { W-C(1) } \\
\text { W-C(2) } \\
\text { W-C(3) } \\
\text { W-C(4) } \\
\text { W-C(5) } \\
P-C(6) \\
P-C(15) \\
P-C(21) \\
S-C(6) \\
S-C(8) \\
N-C(6) \\
N-C(7) \\
N-C(9) \\
C(1)-O(1) \\
C(2)-O(2) \\
C(3)-O(3) \\
C(4)-O(4) \\
C(5)-O(5) \\
C(7)-C(8) \\
C(7)-O \\
B-O \\
B-F(2) \\
B-F(3) \\
B-F(4)\end{array}$ & $\begin{array}{l}2.5185(10) \\
2.047(4) \\
2.077(5) \\
1.982(4) \\
2.040(4) \\
2.024(4) \\
1.842(3) \\
1.825(3) \\
1.827(4) \\
1.669(3) \\
1.691(4) \\
1.353(4) \\
1.399(4) \\
1.456(4) \\
1.131(5) \\
1.120(6) \\
1.154(5) \\
1.137(5) \\
1.144(5) \\
1.353(5) \\
1.304(4) \\
1.500(5) \\
1.377(5) \\
1.369(5) \\
1.367(5)\end{array}$ \\
\hline $\begin{array}{l}P-W-C(1) \\
P-W-C(2) \\
P-W-C(3) \\
P-W-C(4) \\
P-W-C(5) \\
W-P-C(6) \\
W-P-C(16) \\
W-P-C(22) \\
C(6)-P-C(16) \\
C(6)-P-C(22) \\
C(16)-P-C(22) \\
C(6)-S-C(7) \\
P-C(6)-S \\
P-C(6)-N \\
S-C(6)-N \\
S-C(7)-C(8) \\
C(7)-C(8)-C(9) \\
C(7)-C(8)-N \\
C(9)-C(8)-N \\
C(6)-N-C(8) \\
C(6)-N-C(10) \\
C(8)-N-C(10)\end{array}$ & $\begin{array}{l}89.6(3) \\
93.1(3) \\
175.8(4) \\
94.0(3) \\
89.1(3) \\
105.3(3) \\
120.3(3) \\
118.0(3) \\
108.5(4) \\
100.6(4) \\
102.2(4) \\
92.4(5) \\
115.7(5) \\
128.9(7) \\
114.7(7) \\
105.9(7) \\
126.7(10) \\
109.8(8) \\
123.4(9) \\
114.9(7) \\
127.0(8) \\
118.0(7)\end{array}$ & $\begin{array}{l}P-W-C(1) \\
P-W-C(2) \\
P-W-C(3) \\
P-W-C(4) \\
P-W-C(5) \\
W-P-C(6) \\
W-P-C(15) \\
W-P-C(21) \\
C(6)-P-C(15) \\
C(6)-P-C(21) \\
C(15)-P-C(21) \\
C(6)-S-C(8) \\
C(6)-N-C(7) \\
C(6)-N-C(9) \\
C(7)-N-C(9) \\
P-C(6)-S \\
P-C(6)-N \\
S-C(6)-N \\
N-C(7)-C(8) \\
N-C(7)-O \\
C(8)-C(7)-O \\
S-C(8)-C(7) \\
O-B-F(2) \\
O-B-F(3) \\
O-B-F(4) \\
F(2)-B-F(3) \\
F(2)-B-F(4) \\
F(3)-B-F(4) \\
C(7)-O-B\end{array}$ & $\begin{array}{l}88.02(11) \\
90.44(12) \\
175.89(13) \\
96.00(11) \\
92.93(12) \\
114.43(11) \\
112.31(11) \\
115.10(12) \\
104.36(15) \\
101.64(15) \\
107.94(16) \\
93.67(17) \\
113.6(3) \\
125.9(3) \\
120.4(3) \\
118.40(20) \\
131.27(24) \\
110.20(23) \\
112.1(3) \\
115.9(3) \\
131.9(3) \\
110.4(3) \\
110.8(3) \\
104.9(3) \\
108.6(3) \\
111.6(3) \\
109.2(4) \\
111.6(4) \\
122.4(3)\end{array}$ \\
\hline
\end{tabular}

a Bond distances and angles of the three phenyl groups for both complexes are listed in the Supporting Information.

X-ray Analysis of $\mathbf{1 0}$ and $\mathbf{1 2}$. Single crystals of $\mathbf{1 0}$ suitable for an X-ray diffraction study were grown as mentioned above. A single crystal of dimensions $0.10 \times 0.40 \times 0.45 \mathrm{~mm}^{3}$ was glued to a glass fiber and mounted on an Enraf-Nonius CAD4 diffactometer. I nitial lattice parameters were determined from a least-squares fit to 25 accurately centered reflections with $10.0^{\circ}<2 \theta<25^{\circ}$. Cell constants and other pertinent data are collected in the Supporting I nformation. Data were collected using the $\theta / 2 \theta$ scan method. The final scan speed for each reflection was determined from the net intensity gathered during an initial prescan and ranged from 2 to $7^{\circ} \mathrm{min}^{-1}$. The scan angle was determined for each reflection according to the equation $0.8+0.35 \tan \theta$. 
The raw intensity data were converted to structure factor amplitudes and their esd's by correction for scan speed, background, Lorentz, and polarization effects. An empirical correction for absorption, based on the azimuthal scan, was appplied to the data set. Crystallgraphic computations were carried out on a Microvax III computer using the NRCC structure determination package. ${ }^{13}$ Merging of equivalent and duplicate reflections gave a total of 4999 unique measured data, from which 4162 were consi dered observed $(I>2.0 \sigma(I))$. The structure was first solved by using the heavy-atom method (Patterson synthesis), which revealed the position of the metal, and then refined via standard least-squares and difference Fourier techniques. The quantity minimized by the leastsquares program was $w\left(\left|F_{o}\right|-\left|F_{c}\right|\right)^{2}$. The analytical forms of the scattering factor tables for the neutral atoms were used. ${ }^{14}$ All other non-hydrogen atoms were refined by using anisotropic thermal parameters. Hydrogen atoms were included in the structure factor calculations in their expected positions on the basis of idealized bonding geometry but were not refined in least squares. Final refinement using full-matrix least

(13) Gabe, E. J .; Lee, F. L.; Lepage, Y. In Crystallographic Computing 3; Sheldrick, G. M., Kruger, C., Goddard, R., Eds.; Clarendon Press: Oxford, England, 1985; p 167.

(14) International Tables for X-ray Crystallography; Reidel: Dordrecht, The Netherlands, 1974; Vol. IV. squares converged smoothly to values of $\mathrm{R}=0.053$ and $\mathrm{R}_{\mathrm{w}}=$ 0.055 . Crystal and intensity collection data are given in Table 1 , while bond distances and angles are given in Table 2. Final values of all refined atomic positional parameters (with esd's) and tables of thermal parameters are given in the Supporting Information.

The procedures for $\mathbf{1 2}$ were similar. The final residuals of the refinement were $R=0.023$ and $R_{w}=0.018$. Final values of all refined atomic positional parameters (with esd's) and tables of thermal parameters are given in the Supporting Information.

Acknowledgment. We wish to thank the National Science Council of Taiwan, Republic of China, for financial support.

Supporting Information Available: Details of the structural determination for complexes $\mathbf{1 0}$ and $\mathbf{1 2}$, including tables of crystal data and structure refinement, fractional coordinates, anisotropic thermal parameters, and all bond distances and angles (11 pages). Ordering information is given on any current masthead page.

OM970418E 